\title{
IMPACT OF EXTERNAL DEBT ON ECONOMIC GROWTH IN NIGERIA
}

\section{Uzochukwu Ojelubechukwu Fortune}

Department of Economics/Faculty of Management and Social Sciences/Godfrey Okoye University, Thinkers Corner Enugu State, Nigeria.

Email: lubech55@gmail.com

\section{Cite this article:}

Uzochukwu Ojelubechukwu Fortune (2021), Impact of External Debt on Economic Growth in Nigeria. African Journal of Economics and Sustainable Development 4(3), 72-84. DOI: 10.52589/AJESDMZSO1NP8.

\section{Manuscript History \\ Received: 4 Sept 2021 \\ Accepted: 22 Sept 2021 \\ Published: 3 Oct 2021}

Copyright $\odot 2020$ The Author(s). This is an Open Access article distributed under the terms of Creative Commons AttributionNonCommercial-NoDerivatives 4.0 International (CC BY-NC-ND 4.0 ), which permits anyone to share, use, reproduce and redistribute in any medium, provided the original author and source are credited.
ABSTRACT: This study examined external borrowing and economic growth in Nigeria covering the period $1981-2019$. The main objective of the study is to ascertain the impact of external borrowing on economic growth in Nigeria. Times series data on $G D P$, external debt, exchange rate, external debt servicing payments and inflation were extracted from the Central Bank of Nigeria (CBN) statistical bulletin 2018 was used for the study. The method of data analysis and evaluation were the unit-root test which was used to ascertain the stationary status of the variables, the linear regression with the application of Ordinary Least Squares (OLS) technique and the Granger causality analysis. The major findings of the study are that all the variables are stationary at first difference I(1), external debt has a negative and insignificant relationship with economic growth in Nigeria( $=-0004912$, $p$-value $=0.6944>0.05$ ) and there is no causality relationship existing between external debt and economic growth in Nigeria. The study therefore recommends that the federal government should acquire external debt largely for economic reasons rather than social or political reasons. This would increase the Gross Domestic Product (GDP) of the nation.

KEYWORDS: External Debt, Economic Growth, Gross Domestic Product (GDP), Exchange Rate, Nigeria 


\section{INTRODUCTION}

Based on the premise of international trade, no country is self-sufficient. This is also applicable in the concept of finance. Sometimes, a country may need external finance to fund its domestic projects that are targeted towards achieving sustainable economic growth and development. One of those strategies of engaging external assistance is through external borrowing. Udoffia and Akpanah (2016) posit that external debt is a financial package generated from outside the country with the primary aim of facilitating economic growth and development, and repayable at a determined future date in foreign currency. Therefore, external borrowing is a primary source of public receipts.

Over the years, Nigeria has been borrowing externally to support her macroeconomic goals such as employment generation, economic growth, balance of payments deficits and infrastructural projects. Historically, Nigeria's external indebtedness can be traced back to the pre-independence period when in 1958, a financial loan amounting to US\$28 million dollars was contracted from the World Bank for the purpose of railway construction. As at then, this external debt did not pose a serious burden because it was contracted on soft terms, that is the borrowing was with no interest or below the market rate of interest. Following this period, the necessity for foreign assistance was relatively low until in 1977/1978 when there was a downward movement in world oil prices which correspondingly reduced the nation's oil revenues. Before this period Nigeria was experiencing abundance in oil receipts especially with the oil boom of 1973-1976 (Adepoju, Salau, \& Obayelu, 2017).

On the average, Nigeria's external borrowing has been increasing. For instance, in 2009, the external debt stock was N590.44 billion. It further increased to N896.85 billion in 2011, $\mathrm{N} 1,387.33$ billion in 2013, N3,478.91 billion in 2016 and N7,759.20 billion in 2018. A more historical analysis of external debt reveals that between 1981 to 1998, the level of external debt was relatively low. It became higher between 1999 and 2004. It plateaued in 2006 and has maintained an increase ever since. One can say that on the average, the level of external debt has been on the increase.

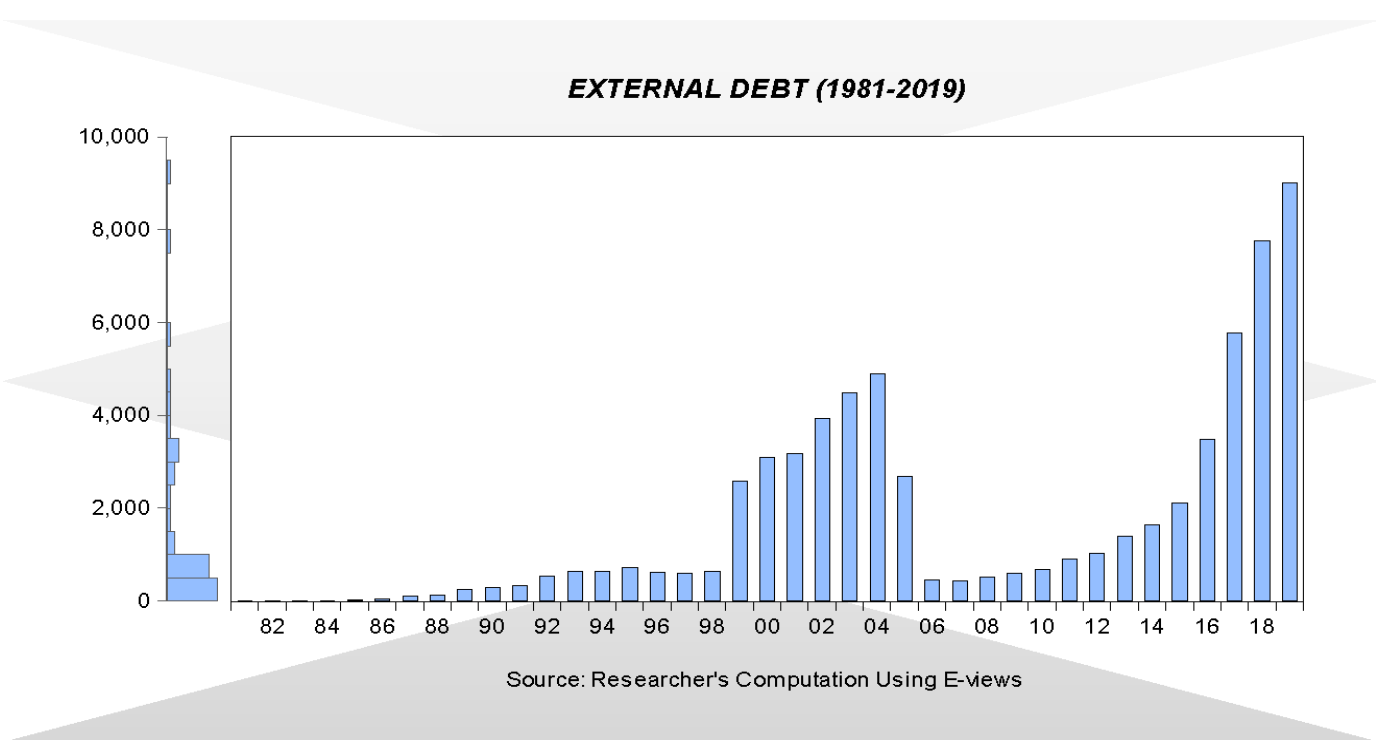

Figure 1 
This increasing external debt stock also brings along with it the cost of debt servicing and maintenance. It becomes pertinent to know if this accumulating debt stock contributes positively or negatively to economic growth and development of the Nigerian economy.

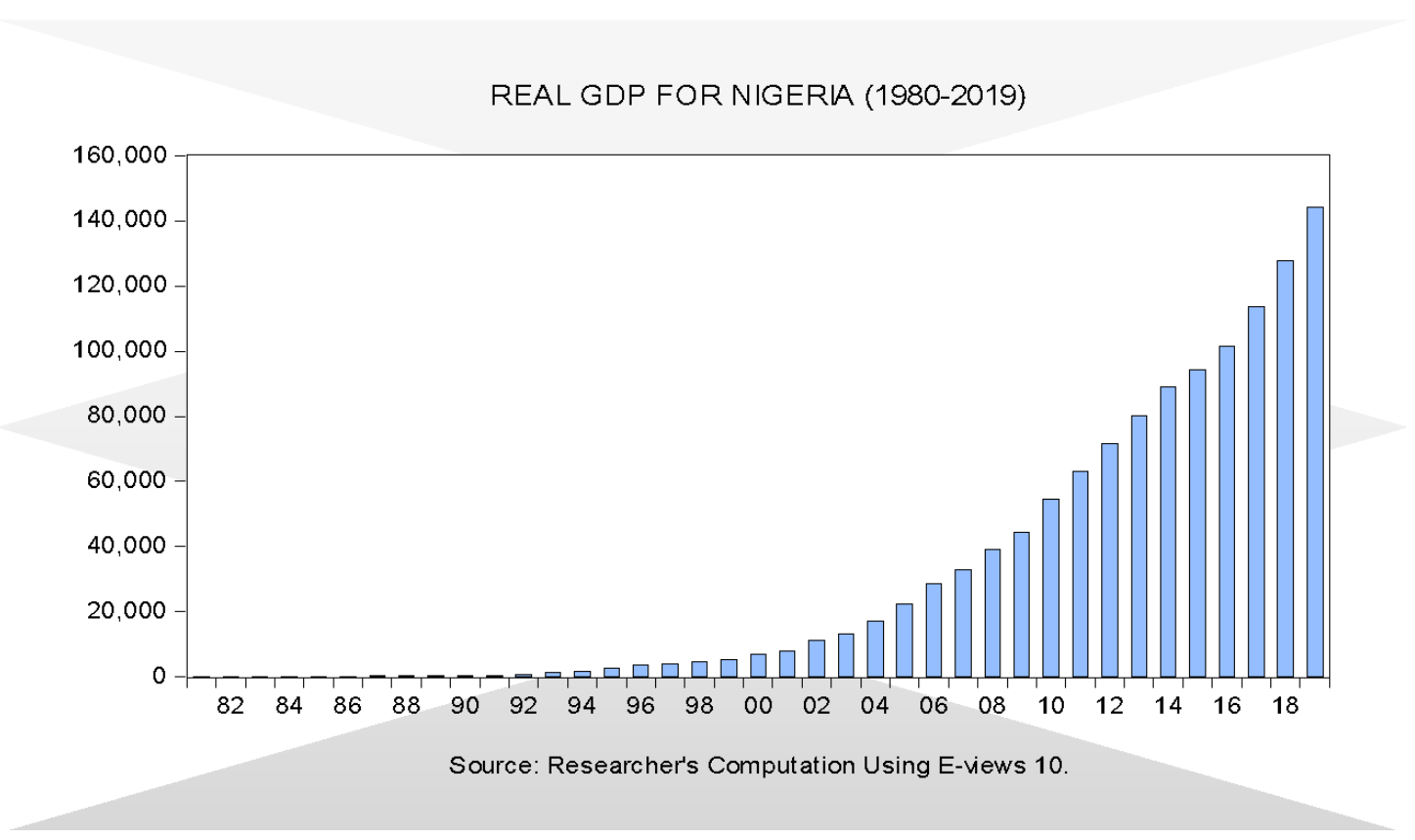

Figure 2

Figure 2 clearly shows that Nigeria's real gross domestic product has been on an increasing path. One begins to wonder whether external debt contributes positively or negatively to economic development of Nigeria for the years under analysis. Based on the foregoing, this study is therefore aimed at carrying out an empirical analysis of the impact of external debt and economic growth in Nigeria covering the period 1981-2019.

\section{LITERATURE REVIEW}

Utomi (2019) carried out an empirical investigation of the impact of external borrowing on economic growth in Nigeria for the period 1980-2017. The techniques of estimation employed in the study include Augmented Dickey Fuller (ADF) test, Johansen Cointegration, Vector Error Correction Mechanism and Granger Causality Test. The results show an insignificant long run relationship and a bi-directional relationship between external borrowing and economic growth in Nigeria.

Udeh, Ugwu and Onwuka (2016) empirically investigated the impact of external debt on economic growth in Nigeria. The study model was formulated and data were analyzed using Ordinary Least Square. Diagnostic tests were conducted using Augmented Dick Fuller Unit Root Test, Co-integration and Error Correction Model. They discovered that external debt had 
a positive relationship with Gross Domestic Product in the short run, but a negative relationship in the long run.

Ajayi and Oke (2012) investigated the effect of the external debt burden on the economic growth and development of Nigeria. It adopted regression analysis of OLS on secondary data sourced from the Central Bank of Nigeria's (CBN) statistical bulletin (2012). The finding indicates that external debt burden had an adverse effect on the gross income and per capita income of the nation. High levels of external debt led to devaluation of the national currency, increase in retrenchment of workers, continuous industrial strike and poor educational system. This led to the economy of Nigeria getting depressed.

Paul (2017) empirically analyzed the impact of external debt on the economic growth of Nigeria. The scope of the study covers the period from 1985 to 2015. Data are analyzed using the ordinary least square regression, ADF unit root test, Johansen cointegration and error correction test. Findings reveal that debt service payment has a negative and insignificant impact on Nigeria's economic growth while external debt stock has a positive and significant effect on Nigeria's growth index.

\section{METHODOLOGY}

This study adopted an Ex post Facto research design. Ex post Facto research design is a quasiexperimental study examining how an independent variable, present prior to the study, affects a dependent variable.

\section{Theoretical Framework}

This study is anchored on the dual gap theory propounded by Chenery in 1996. The dual gap theory asserts that there is a constant need to borrow from foreign sources and this arises from the recognized role of capital in the developmental process of any nation.

\section{Model Specification}

In this research, external debt, debt servicing payments, exchange rate and inflation are specified as the independent and control variables while economic growth measured with rate of growth of real gross domestic product will serve as the dependent variable. The model is specified on implicit and explicit versions thus:

In implicit form: $R G D P=f(E X D, E X D S P, E X R, I N F)$

Explicit:

$R G D P_{t}=\beta_{O}+\beta_{1} E X D_{t}+\beta_{2} E X D S P_{t}+\beta_{3} E X R_{t}+\beta_{4} I N F_{t}+\mu_{t}$

where:

$\mathrm{f}=$ Functional Relationship

RDGP $=$ Rate of Real Gross Domestic Product

EXD $=$ External Debt 


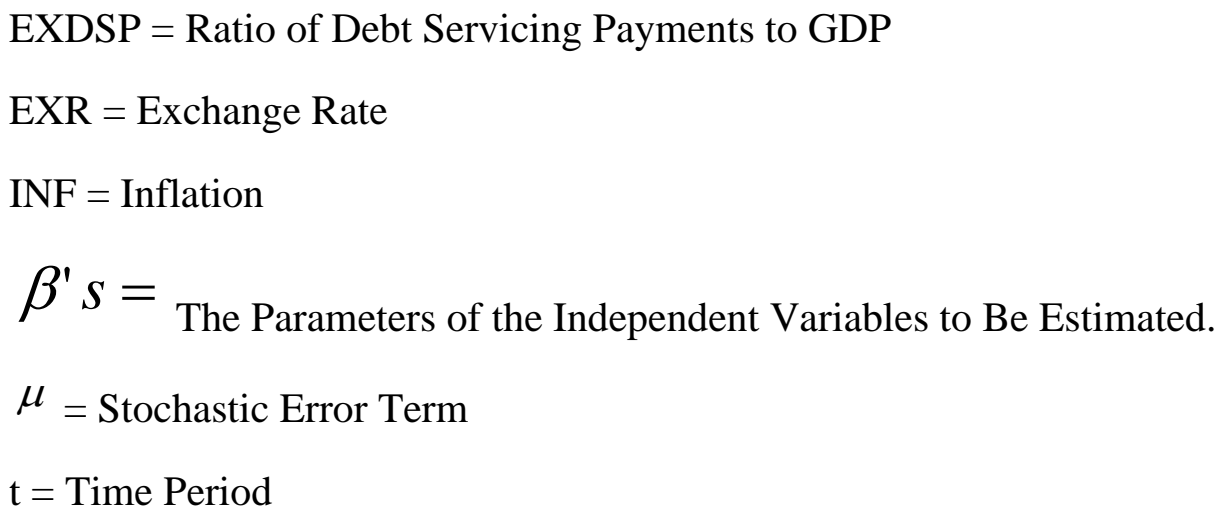

\section{Method of Data Evaluation}

\section{Unit Root/Stationarity Test}

The first step in time series econometric analysis involves testing the order of integration of the individual series under consideration. Researchers have developed several procedures for the test of order of integration. The most popular one is the Augmented Dickey-Fuller (ADF) test. This test is used for the analysis. Augmented Dickey-Fuller (ADF) test is used to test the existence of unit root when there is autocorrelation in the series and lagged terms of the dependent variable are included in the equation.

\section{Decision Rule}

If $\mathrm{ADF}$ test statistic (t-statistic of lagged dependent variable) is absolutely greater than the critical value, we reject the null hypothesis and conclude that the series is stationary (there is no unit root) but if otherwise, we accept the null hypothesis and conclude that the series is not stationary (there is unit root).

\section{Cointegration test}

In this study, the Johansen or Engel-Granger cointegration method will be used depending on the order of integration status of the series. The long-run equilibrium relationship is estimated with the following equation:

$$
\mathrm{X}_{t}=\alpha_{0}+\alpha_{1} \mathrm{Z}_{t}+\varepsilon_{t}
$$

If there is cointegration, $\alpha_{0}$ and $\alpha_{1}$ estimates reveal "super-consistent" estimators in the OLS regression. In this estimation, fitted values of $\mathcal{E}_{t}$ the series are tested for stationarity.

\section{Decision Rule}

For the Johansen method, if the trace statistics is absolutely greater than the critical value at $5 \%$ level of significance, we conclude that the series are cointegrated. If otherwise, we accept the null hypothesis of no cointegration. 
For Engel Granger, if the ADF statistics of residual series is absolutely greater than the critical values at 5\% level of significance, then there exists a long-run relationship between the variables, and if otherwise, there exists no long-run relationship among the variables.

\section{Error Correction Model (ECM)}

After testing for the cointegration relationship and cointegration is proven to exist between the variables, then the third step will require the construction of an Error Correction Model (ECM) to model the dynamics of the relationship. The reason behind ECM is to determine the speed of adjustment from the short-run disequilibrium to the long run equilibrium state. The greater the coefficient of ECM, the higher the speed of adjustment from the short-run disequilibrium to long-run equilibrium. The ECM is given by the equation: $\Delta R G D P_{t}=\beta_{0}+\Delta \beta_{1} E X D_{t}+\Delta \beta_{2} E X D S P_{t}+\Delta \beta_{3} E X R_{t}+\Delta \beta_{4} I N F_{t}+E C M_{t-1}+\mu_{t} \ldots \ldots . .3 .4$

where $\Delta=$ First Difference Operator

\section{Decision Rule}

If the ECM coefficient is $>0.50$, then we conclude that the speed of adjustment is high, but if the ECM coefficient is less than 0.50, we conclude that the speed of adjustment is low.

\section{Autocorrelation Test}

In order to avoid some of the pitfalls of Durbin-Watson d test of autocorrelation, the BreuschGodfrey Serial Correlation LM Test will be used to carry out the test of autocorrelation.

\section{Decision Rule (Autocorrelation Test)}

If the probability value of the Chi-Square $\left(\mathrm{X}^{2}\right)<0.05$, we reject the null hypothesis that there is no serial correlation in the model, but if the p-value of the Chi-Square $\left(X^{2}\right)>0.05$, we accept the alternative that there is no serial correlation in the model.

\section{Granger Causality Model}

The Granger causality model is a statistical technique that was carried out in the direction of causality existing between the dependent variables and the specified independent variables. The Granger causality model was specified thus: 


$$
\begin{aligned}
& R D G P_{t}=\beta+\sum_{i=1}^{n} \gamma_{i} R G D P_{t-i}+\sum_{i=1}^{n} \gamma_{i} E X D_{t-i}+\sum_{i=1}^{n} \gamma_{i} E X D S P_{t-i}+\sum_{i=1}^{n} \gamma_{i} E X R_{t-i}+\sum_{i=1}^{n} \gamma_{i} I N F_{t-i}+\Omega \\
& E X D_{t}=\varphi+\sum_{i}^{n} \theta_{i} E X D_{t-i}+\sum_{i=1}^{n} \gamma_{i} R G D P_{t-i}+\sum_{i=1}^{n} \gamma_{i} E X D S P_{t-i}+\sum_{i=1}^{n} \gamma_{i} E X R_{t-i}+\sum_{i=1}^{n} \gamma_{i} I N F_{t-i}+\psi \\
& E X R_{t}=\varphi+\sum_{i=1}^{n} \gamma_{i} E X R_{t-i}+\sum_{i}^{n} \theta_{i} R G D P_{t-i}+\sum_{i=1}^{n} \gamma_{i} E X D_{t-i}+\sum_{i=1}^{n} \gamma_{i} E X D S P_{t-i}+\sum_{i=1}^{n} \gamma_{i} I N F_{t-i}+\psi \\
& \operatorname{EXDSP}_{t}=\varphi+\sum_{i=1}^{n} \gamma_{i} E X D S P_{t-i}+\sum_{i=1}^{n} \gamma_{i} R G D P_{t-i}+\sum_{i}^{n} \theta_{i} E X D_{t-i}+\sum_{i=1}^{n} \gamma_{i} E X R_{t-i}+\sum_{i=1}^{n} \gamma_{i} I N F_{t-i}+\psi \\
& I N F_{t}=\varphi+\sum_{i=1}^{n} \gamma_{i} I N F_{t-i}+\sum_{i=1}^{n} \gamma_{i} R G D P_{t-i}+\sum_{i}^{n} \theta_{i} E X D_{t-i}+\sum_{i=1}^{n} \gamma_{i} E X R_{t-i}+\sum_{i=1}^{n} \gamma_{i} E X D S P_{t-i}+\psi
\end{aligned}
$$

\section{Decision Rule}

If the probability value of an estimated Granger causality is less than 0.05 , we reject the null hypothesis and conclude that a Granger causality exists, while if the probability value is greater than 0.05 , we accept the null hypothesis and conclude that there exists no causality relationship among the variables.

\section{Data and Sources}

The data used for this research are time series secondary data on average annual external debt stock, external debt servicing payments, exchange rate, inflation and real gross domestic product covering the period 1981-2018. Data were extracted from the Central Bank of Nigeria (CBN) statistical bulletin, 2018.

\section{Econometric Software for the Work}

The software used in this research is the E-views version 10 . The primary purpose of using this software is because the data for the study is secondary in nature.

\section{RESULTS AND ANALYSIS}

\section{Unit Root Test}

The first step in this analysis is to test for stationarity using Augmented Dickey Fuller (ADF) and Phillips-Perron (PP) test. The decision rule based on the ADF and PP tests is that their statistics must be greater than Mackinnon Critical Value at 5\% level of significance and at the absolute term. The result of this test is shown below: 
Table 4.1: Result of Unit Root Test

\begin{tabular}{|l|l|l|l|l|l|}
\hline Variables & ADF Stat. & $\begin{array}{c}\text { Critical Val } \\
\left(\begin{array}{c}\text { ADF } \text { at } \\
\mathbf{5 \%}\end{array}\right.\end{array}$ & PP Stat. & $\begin{array}{c}\text { Critical Val } \\
(\text { PP) at 5\% }\end{array}$ & $\begin{array}{c}\text { Order of } \\
\text { Integration }\end{array}$ \\
\hline RGDP & -3.088105 & -2.945842 & -6.127644 & -2.943427 & $\mathrm{I}(1)$ \\
\hline EXD & -2.672812 & -1.950117 & -2.639600 & -1.950117 & $\mathrm{I}(1)$ \\
\hline EXDSP & -3.340024 & -1.950117 & -7.887011 & -3.536601 & $\mathrm{I}(1)$ \\
\hline EXR & -4.815163 & -3.536601 & -4.810534 & -3.536601 & $\mathrm{I}(1)$ \\
\hline INF & -5.318822 & -3.548490 & -11.92000 & -3.536601 & $\mathrm{I}(1)$ \\
\hline
\end{tabular}

Source: Researcher's Computation Using E-views 10.

The result in the table above reveals that all the variables in the model are non-stationary at all levels. Based on this, the variables were differenced to see their outcome. The result of the $\mathrm{ADF}$ and PP tests shown in tables 4.1 above indicates that all the variables are integrated of the same order one; that is I(1).

\section{Cointegration Analysis (Johansen Method)}

The cointegration test is used to check for long run relationships between the dependent and independent variables. The cointegration test was carried out using the Johansen technique and it produced the following results:

\section{Table 4.2}

Date: 30/08/21 Time: 07:50

Sample (adjusted): 19832019

Included observations: 37 after adjustments

Trend assumption: Linear deterministic trend

Series: RGDP EXD EXDSP EXR INF

Lags interval (in first differences): 1 to 1

Unrestricted Cointegration Rank Test (Trace)

\begin{tabular}{ccccc}
\hline $\begin{array}{c}\text { Hypothesized } \\
\text { No. of CE(s) }\end{array}$ & Eigenvalue & $\begin{array}{c}\text { Trace } \\
\text { Statistic }\end{array}$ & $\begin{array}{c}0.05 \\
\text { Critical Value }\end{array}$ & Prob.** \\
\hline None ${ }^{*}$ & 0.601705 & 83.31780 & 69.81889 & 0.0029 \\
At most 1 & 0.438118 & 49.25704 & 47.85613 & 0.0367 \\
At most 2 & 0.347086 & 27.92792 & 29.79707 & 0.0809 \\
At most 3 & 0.231507 & 12.15447 & 15.49471 & 0.1497 \\
At most 4 & 0.063097 & 2.411492 & 3.841466 & 0.1204 \\
& & & & \\
\hline
\end{tabular}

Trace test indicates 2 cointegrating eqn(s) at the 0.05 level

$*$ denotes rejection of the hypothesis at the 0.05 level

**MacKinnon-Haug-Michelis (1999) p-values

Source: Researcher's Computation Using E-views 10. 
The result of the cointegration analysis from table 4.2 above indicates that at most two (2) cointegrating equations exist at $5 \%$ level of significance. This is shown from the trace statistics of at none and at most $1 *$ whose p-values are $0.0029<0.05$ and $0.0367<0.05$ respectively. This however implies that there is a long run relationship between RGDP, EXD, EXDSP, EXR and INF in the model.

\section{Regression Analysis (OLS Technique using Error Correction Mechanism)}

Table 4.3

Dependent Variable: D(RGDP)

Method: Least Squares

Date: 30/08/21 Time: 07:59

Sample (adjusted): 19822019

Included observations: 38 after adjustments

\begin{tabular}{ccccc}
\hline Variable & Coefficient & Std. Error & t-Statistic & Prob. \\
& & & & \\
\hline C & -0.013627 & 0.046927 & -0.290377 & 0.7734 \\
D(EXD) & -0.004912 & 0.012391 & -0.396432 & 0.6944 \\
D(EXDSP) & -0.039380 & 0.013507 & -2.915466 & 0.0064 \\
D(EXR) & -0.034415 & 0.020829 & -1.652260 & 0.1083 \\
D(INF) & -0.009646 & 0.008576 & -1.124841 & 0.2690 \\
ECM $(-1)$ & -0.131850 & 0.068466 & -1.925786 & 0.0631
\end{tabular}

$\begin{array}{lllr}\text { R-squared } & 0.561911 & \text { Mean dependent var } & 0.042496 \\ \text { Adjusted R-squared } & 0.462209 & \text { S.D. dependent var } & 0.060540 \\ \text { S.E. of regression } & 0.052001 & \text { Akaike info criterion } & -2.931186 \\ \text { Sum squared resid } & 0.086530 & \text { Schwarz criterion } & -2.672619 \\ \text { Log likelihood } & 61.69253 & \text { Hannan-Quinn criter. } & -2.839190 \\ \text { F-statistic } & 3.629943 & \text { Durbin-Watson stat } & 1.940189 \\ \text { Prob(F-statistic) } & 0.010303 & & \end{array}$

Source: Researcher's Computation Using E-views 10.

Table 4.3 shows that external borrowing or debt stock (EXD) yielded a negative numerical coefficient at the magnitude of -0.004912 . This entails that a $1 \%$ increase in external debt decreases the growth rate by 0.004912 on average and vice-versa. This result conforms to economic a priori expectation because an increase in external debt also entails an increase in debt servicing, which in turn deteriorates economic growth. The rationale behind this claim is that the resources used in servicing external debt should have been utilized in engaging in projects that would have generated economic growth and development. This result is purely a reflection of a true situation in Nigeria. It reveals that external funds borrowed are not 
adequately utilized and channeled to projects that will generate optimal growth and development.

External debt servicing payments to GDP (EXDSP) yielded a negative coefficient at the magnitude of-0.039380. This clearly shows that external debt servicing contributes negatively to economic growth in Nigeria. This conforms to economic a priori expectation because payments extended for debt servicing should have been pumped into the economy to generate growth and development.

The regression table shows that the coefficient of exchange rate yielded -0.034415 . This entails that exchange rate fluctuation contributes negatively to economic growth in Nigeria. This conforms to economic a priori expectation because volatility in exchange rates is expected to keep the investors - both domestic and external — uncertain and thereby discourage investment and reduce economic growth.

Finally, the regression result shows that the inflation coefficient yielded a negative coefficient at the magnitude of -0.009646 . This entails that as inflation rate increases in a domestic economy like Nigeria, economic growth decreases. This conforms to economic a priori expectation because inflation increase entails increases in average price. This discourages aggregate demand and through the simple multiplier effect reduces economic growth.

The result of F-statistic is 3.629943 and the probability of F-statistic is 0.010303 which implies that the overall regression is statistically significant. This also means that all the independent variables taken together will impact significantly on the growth of the Nigerian economy.

The result in the table above also shows that $\mathrm{R}$-squared value is 0.561911 , which implies that $56.19 \%$ of the variation in GDP is explained in the model, leaving only less than $45 \%$ to the error term. This also means that the line of best fit was highly fitted. Hence, this model is the best model to explain the relationship between the variables under consideration.

The coefficient of the $\operatorname{ECM}(-1)$ on the other hand indicates that $13 \%$ of the disequilibrium in the short run will be corrected annually. In other words, $13 \%$ of the disequilibrium in the short run will be corrected in the long run. The insignificant result in the ECM implies that the speed of adjustment will be very slow.

\section{Autocorrelation Test (Breusch-Godfrey)}

\section{Table 4.4}

Breusch-Godfrey Serial Correlation LM Test:

$\begin{array}{llll}\text { F-statistic } & 1.387189 & \text { Prob. F(2,30) } & 0.2653 \\ \text { Obs*R-squared } & 3.216731 & \text { Prob. Chi-Square(2) } & 0.2002\end{array}$

Source: Researcher's Computation Using E-views 10. 
The result of the serial correlation shows a probability value of 0.2002 which is greater than 0.05 indicating the acceptance of Ho. This entails that there is no serial correlation in the model; hence, the model is free from autocorrelation problems.

\section{Granger Causality Analysis}

\section{Table 4.5}

Pairwise Granger Causality Tests

Date: 07/10/21 Time: 08:25

Sample: 19812019

Lags: 2

\begin{tabular}{lccc}
\hline Null Hypothesis: & Obs & F-Statistic & Prob. \\
& & & \\
\hline EXD does not Granger Cause RGDP & 37 & 0.90526 & 0.4145 \\
RGDP does not Granger Cause EXD & & 2.35669 & 0.1110
\end{tabular}

Source: Researcher's Computation Using E-views 10.

Our focus is on the causal relationship between external debt (EXD) and economic growth (RGDP). The null hypothesis states that EXD does not Granger Cause RGDP and RGDP does not Granger cause EXD. The rule of thumb states that the probability of F-statistic must be less than 0.5 to show causal relationship. The probabilities for our causal variables RGDP and external debt stock are $0.4141>0.05$ and $0.1110>0.05$. Therefore, we accept the null hypothesis and conclude that no causal relationship exists between external debt and economic growth in Nigeria for the period under analysis.

\section{Hypotheses Testing}

Table 4.6

\begin{tabular}{|l|l|}
\hline Variable & Probability Value \\
\hline EXD & 0.6944 \\
\hline
\end{tabular}

Source: Main Regression Output (Table 4.4)

From table 4.6, we can clearly see that the probability value of external debt (EXD) yielded 0.6944 and this is greater than 0.05 . This compels us to accept $\mathrm{H}_{\mathrm{o} 1}$ and therefore conclude that external debt has no significant impact on economic growth in Nigeria.

The granger causality result in table 4.5 clearly shows that there exists no directional causality relationship between external debt and real gross domestic product. Hence, the $\mathrm{H}_{\mathrm{o} 2}$ is rejected and it is concluded that there is a causality relationship between external debt and economic growth in Nigeria. 


\section{DISCUSSION OF RESULTS}

The discussions of findings were done in line with the objectives of the study.

The first objective of the study was to ascertain the impact of external borrowing on economic growth in Nigeria. The finding was that external debt has a negative relationship with economic growth in the short and long run. This means that as debt increases, GDP decreases and vice versa. The a priori expectation is that debt would enhance economic growth in line with the economic theory. The result was not so. Instead, debt had a negative impact on economic growth. The negative relationship between external debt and economic growth might be due to the fact that even though debt provided the much-needed fund, it might not have been used on productive ventures where the returns should be more than the interest payable. This may be due to poor policy formulation, misappropriation, embezzlement and other corrupt practices. The above view was echoed by Okoye and Ani (2019) when they stated that nations must avoid waste and inefficiency while they strive to ensure proper setting of social priorities. Too much stock of debt may result in debt overhang. Excessive debt servicing drains resources thus reducing funds available for development.

The second objective of the study was to ascertain the causality relationship between external borrowing and economic growth in Nigeria. It was discovered that there is no causal relationship existing between external debt and economic growth in Nigeria. This entails that external borrowing does not have the prospect of tremendously boosting economic growth in Nigeria. Therefore, Nigeria should minimize its external borrowings.

\section{CONCLUSION}

External debts are necessary to meet shortfall in internal resources, and stimulate the economy. However, it must be properly utilized to avoid serious consequences. Borrowing is not the most important issue but the use to which the fund is deployed. This should be the most important thing any good economist should agitate whenever external debt is contemplated. It should be approached with caution, ensuring optimal utilization and higher return than the interest (cost of fund). To sum up, external debt stock, debt service payment and other external control variables have a negative impact on the Nigerian economy.

\section{RECOMMENDATIONS}

The study made the following recommendations, which are aimed at ensuring efficient utilization of external debts in Nigeria.

1. It was discovered that external debt has a negative contribution to economic growth in Nigeria. In line with this, the federal government should acquire external debt largely for economic reasons rather than social or political reasons. This would increase the productivity of the nation.

2. Stability in the exchange rate should be pursued and depreciation in the Naira should be avoided by the government. 
3. Government should press for permanent debt relief through strategic and political negotiations so as to avert the debt overhang problem.

\section{REFERENCES}

Adepoju, A.A., Salau, A.S, \& Obayelu, A.E. (2017). The effects of external debt management on sustainable economic growth and development: Lessons from Nigeria, MPRA. Paper No. 2147.

Ajayi, L.B \& Oke, M.O (2012). Effect of external debt on economic growth and development of Nigeria. International Journal of Business and Social Science, 3(12), 111-119.

Paul, N. (2017). Analysis of the impact of external debt on economic growth in an emerging economy: Evidence from Nigeria. African Research Review, 11(4), 156-173.

Udoffia, F.D \& Akpanah, W.A. (2016). Debt servicing and economic growth in Nigeria: An empirical investigation, Global Journal of Social Sciences, 8(2), 1-11.

Udoh, S.U., Ugwu, I.G \& Onwuka, A.C (2016). Effect of external borrowing and foreign aid on economic growth in Nigeria. International Journal of Academic Research in Business and Social Sciences, 6(4), 57-69.

Utomi, W.A. (2019). Debt servicing and economic growth in Nigeria: an empirical investigation, Global Journal of Social Sciences, 8(2), 1-11. 